\title{
MULTICULTURALISM AND SOCIAL INCLUSION IN MEDIEVAL ARAB-MUSLIM CULTURE
}

\author{
Dr. Farooq Hassan *
}

\begin{abstract}
Arabia of Middle ages harbored diversity and hosted various religions such as Judaism and Christianity, the Prophet (PBUH) tried to establish harmonious relations with them to ensure peace and was able to unite them in a single mosaic. Many of the Prophet's (PBUH) companions who were settled in Medina had different geographical, racial and religious backgrounds. He (PBUH) made people feel comfortable with a welcoming behavior, and it was a privilege to be minority and weak. Diplomatic emissaries were also well received by the Prophet in Medina. The State of Medina became a training venue for specializing in different languages including Hebrew, Persian, etc. leading to strengthened ties with people of other cultures. Racism means excluding people because of color, is there racism in Islam? Islamic tradition is more tolerant of race and its commitments stress on racial equity. This work discusses that to what extent did openness towards other cultures and civilizations exist in the early Muslim community? How can Seerah heritage enable Muslims (locally and globally) to confront the historic and contemporary challenges whose impacts are still being felt to this day as (dis) integration in modern societies?
\end{abstract}

Keywords: Coexistence, Multiculturalism, racism, community inclusion, the Arab pagans (mushrikun)

\section{Literature review}

A lot of debate is going on with fears of multiculturalism failure due to Islam (Anshuman Mondal) ${ }^{1}$ (Shireen 2010) ${ }^{2}$ (Thomas 2018) ${ }^{3}$ (Tina, Peter $2019)^{4}$ or believes that Islam is not compatible with it. Seerah literature is rich in reflecting multicultural trends in medieval times. There is a need to showcase the existence of multiculturalism from the earliest Islamic period. Therefore, to showcase the broad spectrum of Islam disregard of color and race this paper has used qualitative, historical, and archival research methods to explore the notion of multiculturalism in the medieval Arab-Muslim era.

\footnotetext{
* Associate Professor, Humanities Department, NED University of Engineering \& Technology Karachi, - Pakistan

drfarooq68@yahoo.com or mfhassan@ neduet.edu.pk
} 


\section{Introduction}

\section{Multiculturalism: A Key Global and Local Challenge}

Multiculturalism has been one of the core values of several Western societies but has faced considerable opposition for some decades. Much of this opposition arose in the context of terrorism committed in the name of Islam, perceptions of Muslim-minorities as resistant to integration, and a perception of Islam as incompatible with norms and values of the West. Most multicultural societies in the West are the result of immigration policies that have facilitated the settlement of people with various ethnicities, languages, and faiths. Muslims are thought to be the failure of multiculturalism and the death of pluralism. Several multicultural countries, including Australia, Canada, New Zealand, and the USA, were established as settler colonies that displaced, subjugated, and/or attempted to subjugate their indigenous populations. They also maintained long periods of immigration restrictions to encourage racial homogeneity and dominance of settler populations. In the latter half of the twentieth century, these countries relaxed their immigration policies with the approach of incorporation of immigrants by raising awareness about assimilation and multiculturalism.

How is Multiculturalism defined and how a multicultural society is formed? There are several definitions of Multiculturalism, all of them more or less emphasize that it is about removing cultural differences and embracing diversity. Edith B. Ordway defines multiculturalism as "A Multicultural Society cultivates, refines, develops, nourishes, fosters, cherishes and promotes harmony. It does not stifle or discourage the religious and cultural rites of people". ${ }^{5}$ Other definitions of multiculturalism are:

"A Multicultural Society disregards cultural differences. It has harmony, meaning people live and work in a peaceful and cooperative relationship and respect one another's attitudes and opinions". ${ }^{6}$

"Multiculture embraces all the essential and necessary categories of human culture, material culture, economic life, social life, customs, and religions". 7 And,

"Where different cultures of distinctive races and religions meet and mix. The Multicultural Society can be called "a Melting Pot "such a society experiences Acculturation meaning, to act with many cultures resulting in Renaissance, revival, and advancement of cultures". ${ }^{8}$

In a socially inclusive society, people of all origins, religions, and ages feel valued, their differences are respected, and their basic needs are met so that they can live with dignity. Such a society has core values of equity, equality, social justice, human rights, and freedoms. Whereas a socially 
exclusive society is one where human rights are not guaranteed, and marginalization is common. On the other hand, Tariq Modood noted ${ }^{9}$ that people identified in a group based on religion or race may be treated by others as backward or inferiors, and lacking rationality.

\section{Dialogue between Islam and its Neighboring Cultures}

Pre and early Islamic Arabia was connected to ancient civilizations, Mesopotamia, Egypt, and Iran. It also had trade links with Ethiopia, India, and China. Thus, the people of Arabia extensively traveled to the ancient regions which led to establishing religious, cultural, business, and diplomatic ties. Arab-Indian trade history (for spices, gold, and African goods, etc. through the West Coast of India) goes too long before the birth of the Prophet of Islam. As Arab converted to Islam they exported their faith along with other commodities. One of the stories tells that probably Cheraman Juma Masjid in Kerala (India), was founded in 629 A.D, when some Indians visited Arabia, embraced Islam, and came back. ${ }^{10}$ It is reported that at least twenty-five companions visited Medieval India. ${ }^{11}$ While mentioning Pre Islamic Arab relations with the rest of the world, Hamidullah says that Chinese traders sailed as far as Basra and Oman. People from all over Iran, China, India, and Sindh used to gather in Dibar for the annual carnival. ${ }^{12}$ Islam entered Africa within five years of its birth in $615 \mathrm{AD}$, and interfaith activities initiated there because first Muslim emigrants easily found two traders' boats on Sea Port and paid half a Dinar to take them to Abyssinia. This shows that Arabia had trade links with Africa. Arabia was a region in which various faiths were present such as Christianity, Judaism, Zoroastrianism, polytheism, Sabi'in, Hunafa, and others not affiliated with any religion. Yemen was subordinated by the Abyssinian rule in 494 A.D, yet there resided Zoroastrians who paid Jizya to the Prophet (PBUH) after the advent of Islam. ${ }^{13}$ Nijran was the biggest epicenter of Christianity and Blazari mentioned that there were also Jews who were part and parcel of treaties. Evidence shows that during the reign of Abu Bakr (first Caliph of Islam) a treaty was signed with the Christian community of Njran in which Jews were also included. ${ }^{14}$ During the reign of Umar (second Caliph), Arfaja bin Harsama was appointed governor of Mosul (presently a city of Iraq), there were Christian churches and a town of the Jewish community. ${ }^{15}$ Al-Bahrayn, Oman, Hadhramaut, and the coastal towns of Eastern Arabia were under Persian Sasanian rule when Islam emerged as a dominant force. When Bahrain's ruler Munzir ibn Sawa came into contact with Islam there were Jews, Christians, Zoroastrians, non-Arabs, and a minority of horse worshipers. ${ }^{16}$ Arab traders would export leather and woolen cloth to Abyssinia and import edibles to Makkah. Although a significant number of Jews resided in 
Medina their settlements were also found in many cities of Hijaz, as Blazari mentioned that Jewish merchants and their families were present in Tai'f ${ }^{17}$ and Wadi al-Qura respectively. ${ }^{18}$ It is reported that on listening to the news of the birth of the Prophet Muhammad (PBUH), a Jew trader and scholar visited the house of the Prophet in Makkah. ${ }^{19}$ Similarly, the Christian community was well settled in Najran but their existence was visible in many other areas too as in 619 A.D, Addas, a Christian slave met the Prophet in Tai'f and embraced Islam. ${ }^{20}$ Jufaina al Ibadi, caregiver of Saad bin Abi Waqqas (r) was Christian from Hira (current Iraq) origin $^{21}$.

Tabari narrates that the Quran (85:4) condemned the pre-Islamic genocide of the Christians of Najran (being burnt to death in the pits of fire because of their religion). In the exegesis of (Q,30:1-2) it is mentioned that during the Makkan period the Muslims wanted the Byzantines (Roman's Christians) to prevail against the Persians because they were People of the Book. The Makkans had their sympathies with the Persians ${ }^{22}$. Islamic sacred texts, the Qur'an and Hadith, discuss the status of Ahl-e-Kitab (Christian and Jews) and Zoroastrians (a religion of Persian origin) and provide guidelines for the relationship with them. The leaders of Jewish tribes of Medina and the Christian community of Nijran came to the Prophet (PBUH) for dialogue with their own religious identities without any fear. Jews, Muslims, and Christians shared ancestry and values. Apart from some Muslim-Jewish encounters in Medina, overall relations were normal. Faith offers common ground for peaceful coexistence which is also reflected from Islamic texts (Qur'an 3:64). The Constitution of Medina and the Treaty with the Jews covered many areas, they were not forced to accept Islam as their religion and Muhammad (PBUH) as their Prophet. Muslim and Jewish communities of Medina were expected to honor this agreement because peace within the Medinan communities was the key to move forward.

The Prophet (PBUH) adopted the Persian and Roman strategies and practices that were beneficial for the community and non-contradictory with the spirit of Islam. When the Battle of Trench was imposed in 627, the Prophet was briefed by Salman Farsi about their strategy of defense in the same situation in Persia ${ }^{23}$. Persian Zoroastrian Empire at that time was more advanced in science, technology, architecture, etc. The Prophet (PBUH) not only accepted a Persian-oriented proposal for the defense of Medina but also participated in digging trenches to motivate his companions $^{24}$. Salman, the originator of the strategy, knew exactly how wide and how deep the trench would have to be; and having worked with the Bani Qurayzah, he knew that they possessed all the implements that 
were needed ${ }^{25}$. The Prophet used products made by foreigners as he ate cheese made in Persia ${ }^{26}$, wore shawls made in Syria, Egypt, and Yemen ${ }^{27}$. $\mathrm{He}$ also wore a Byzantine cloak having tight Sleeves ${ }^{28}$ and Syrian and Egyptian caps $^{29}$. Najashi presented the Prophet with two black plain leather socks (khuff), so he can wear them ${ }^{30}$. The Prophet made sincere efforts for cross-cultural relationships through oral, verbal, and written communication and with the exchange of presents. He initiated communication with the leaders of the great empires like Roman, Persian, and Ethiopians. He also exchanged gifts with some of them. The King of Iliya (Jerusalem) sent a white Mule and the Prophet sent him a garment and wrote him a confirmation of the treaty concerning his country ${ }^{31}$.

Diversity within the Prophet's (PBUH) house and his interaction with people of other cultures

The Prophet's house was a center of diversity and his life was full of examples that accommodated social changes. He came into contact with people of various traditions as he (PBUH) was born in the city of Makkah and sent out to be educated in Bedouin cultural values to Hawazin tribe (Banu Saad) where Bibi Halima (his wet-nurse) and Sheema (the foster sister) both were non- Muslims. Umm Ayman, who took care of him after the death of his mother, had Abyssinian ancestry. The Prophet (PBUH) interacted with Bahira, a Syrian Christian priest at the age of twelve. After the first revelation, Bibi Khadija (R.A) consulted her cousin Waraqah b. Nawfal b. Asad, who was a Christian. The Prophet (PBUH) married women of Jewish descent, such as Safiya (r) bint Hyuui bin Akhtab (from Banu Qurayza) ${ }^{32}$, Raihana (r) bint Zayd (from Banu Nadir) ${ }^{33}$. Maria, mother of a son of the Prophet Muhammad (PBUH) named Ibrahim had a Coptic Christian origin ${ }^{34}$. When Prophet Muhammad (PBUH) received the first revelation in $622 \mathrm{AD}$, slavery and slave trading were central features in human life and society everywhere on this planet. Many of his (PBUH) freed slaves belonged to different civilizations, e.g. Abu Nafa'i b. al-Azraq b. Qais, al-Kharji had Roman origin ${ }^{35}$, while Abu Rafi Ibrahim had Coptic Christian background before Islam ${ }^{36}$. Mujebullah Nadvi has mentioned a list of 70 companions (63 male and 7 female) of the Prophet Muhammad (PBUH), who were Christians or Jews before embracing Islam ${ }^{37}$. The Prophet used Abyssinian (Habashi) and Persian words as "Sanah, Sanah" which means good (beautiful) ${ }^{38}$, and "Kakh, Kakh" which means to stop in Persian language ${ }^{39}$ and al-Harj, which means "killing" in the Ethiopian language ${ }^{40}$. The Prophet's social connectedness is explicitly reflected from Seerah's heritage as his exemplary relationship with non-Arab neighbors. Imam Muslim reported that he accepted his Persian neighbor's invitation and went to his house for a special kind of soup with Bibi Aisha (his 
wife $)^{41}$. Aisha reported that she watched from her apartment the Ethiopians were playing with their spears in the Masjid Nabwi ${ }^{42}$. The Prophet gave respect to the funeral of a Jew ${ }^{43}$, visited a Jewish boy who used to serve the Prophet and became $\mathrm{ill}^{44}$, and bought some food items on credit from a Jewish $\operatorname{man}^{45}$. He (PBUH) welcomed and provided hospitality to about one hundred and ten delegations from across Arabia ${ }^{46}$. The Prophet (PBUH) considered cultural norms of other civilization in legal matters as it is reported that the Prophet was thinking of forbidding intercourse with a breastfeeding woman when he came to know about the Romans and Persians; that they have intercourse with their wives during the breastfeeding period and their children were not harmed by that at all, he $(\mathrm{PBUH})$ did not forbid it ${ }^{47}$. The Prophet wanted to send a letter to the non-Arabs, Chosroes, Caesar, and Negus, and it was said to him that the non-Arabs do not read a letter unless it has a seal on it, he, therefore, acquired a ring of silver to use on $\mathrm{it}^{48}$. Linguistic diversity was appreciated in the Qur'an (Q.30:22) as a sign of God's creation. The Prophet (PBUH) commanded Zaid $b$. Thabit to learn the Hebrew language for better understanding with people of different faiths and beliefs. Abdullah $b$. Zubair (ra) was an expert in many languages. Hakim reported in his alMustadrak that Abdullah b. Zubair (ra) had many slaves from different nations and he used to talk to them in their mother languages ${ }^{49}$. It indicates that the role of language cannot be underestimated to break down the stereotypes of a community and to foster a culture of interfaith understanding.

\section{Efforts to Combat Racism for a Cohesive Society}

How did the early Muslim society deal with the challenges of racism and hatred? Assimilation is a two-way process and cannot take roots in any society (medieval or modern) if there is any kind of discrimination. Were Arab supremacist hate crimes seen against blacks in the Medieval Muslim Arabian Peninsula? The Arabic term ' $A b d$ ' has a double meaning, a slave and a servant, slaves were considered property and they lacked a legal identity of their own. What was the status of slaves during the early Islamic period? Black Muslim families and individuals of Medieval Arabia, children of African Arabs were proud to see themselves first as Muslims before being black. They were never asked by Arab Muslims to justify their settlement on Arab soil and no one raised the issue of ethnic cleansing or racial segregation. The Prophet (PBUH) addressed racial stereotypes, promoted trends of interracial friendships, and appreciated diversity at all levels. He said, "You should listen to and obey your Imam (Muslim ruler) even if he was an Ethiopian (black) slave whose head looks like a raisin ${ }^{150}$. Non-Arabs were given high respect and status because of 
their piety and capability as Bilal b. Rabaha (d. 23 A.H/644 A.D) was born in slavery and had an Abyssinian family background was chosen for his fine voice to be the first to chant the words of the adhan calling Muslims to prayer despite his imperfect pronunciation of Arabic ${ }^{51}$. This gesture was nothing less than revolutionary for that time and place. Once Umar (R.A.) said, "Abu Bakr (R.A.) is our leader who freed our leader Bilal"52. To remove the feeling of racial segregation, once the Prophet (PBUH) said that after my real mother, Umm Ayman (Barakah) is my mother ${ }^{53}$. Umm Ayman was an African-origin lady, who looked after him during his childhood after the death of his real mother (Amina) at the age of six. A black woman used to take care of the Mosque, the Prophet noticed she was not being seen and asked about her"54. Many of the companions of the Prophet (PBUH) had different religious and ethnic backgrounds but they never felt marginalized, for example Abu Hurayrah (d.57 h/676) converted from sun worship to Islam at the age of thirty ${ }^{55}$. The Prophet advised his companions to deal amicably with Coptic, an Egyptian rooted branch of Christianity $^{56}$. It was because Maria, the mother of Ibrahim, had Egyptian Coptic ancestors. According to Al-laith, it was because Hajira, mother of Ismail (AS) belonged to Egypt ${ }^{57}$. Once Abu Dhar (r) said to another companion (RA), O son of black women ${ }^{58}$, on that the Prophet (PBUH) said. "O Abu Dharr! Have you ridiculed him on account of his mother? Indeed you are a man in whom there are traits of Jahiliyya (pre Islamic era) ${ }^{59}$. Ajam (non-Arabs) were mentioned before the Prophet, and he said, "I am supported more by them, or by some of them than I am by you, or some of you." It is said that Isnad of this Hadith is Daiaf, but for the Manaqib (virtue), such Hadiths are accepted ${ }^{60}$.

The Prophet (PBUH) was trying to create a much larger sense of human belonging in the tribal settings, therefore, the tribal system was needed to be restructured. Once the Prophet was traveling with Julaybib, and their caravan was attacked by enemies. When the war was over, the Prophet gathered his followers and asked about the casualties and missing persons, different tribes reported about martyred from their families and clans because every tribe was owning their tribal people. The Prophet inquired about Julaybib, who neither had tribal identity nor lineage and was missing. Finally, the Prophet was informed about his martyrdom. He asked for a grave to be dug and held the body of Julaybib. The Prophet repeatedly said this three times, "he is from me and I am from him". It also means no matter who is your descendent but we have an obligation to one another as a human family ${ }^{61}$. Once a dispute occurred between an Ethiopian and a Coptic slave of the Prophet (PBUH), they abused each other by racist remarks "O Ethiopian and O Coptic". The Prophet (PBUH) 
reconciled between both and said, "You shall not say this and you both are from my family"62. Thus, the Prophet discouraged the growth of racist trends in all its forms and at all levels.

Christian missionary activities were also going on in Medina, Imam Qurtabi states that an Ansar reported to the Prophet that his two sons accepted Christianity at the hands of Syrian Christian traders in Medina. On that occasion, the verse (Qur'an 2:256) was revealed ${ }^{63}$. Once Umar (r) invited an old Christian lady to Islam, but she refused. Umar said 'O Allah be a witness' and recited (Qur'an 2256), 'There is no compulsion in Religion" ${ }^{64}$. She chose to remain Christian and stay in Arabia. It is obvious that force, especially in the matter of religion, will destroy the possibility of social cohesion. That is why no one was forced to accept Islam. The Qur'an (49:13) states that Allah made the human family into sha'b (Pl shu'ub) and Qabila (P1 Qaba'il) just for identification, not for feelings of supremacy due to ethnicities. The Prophetic messages on many occasions especially in the last sermon explicitly condemned justifying feeling of superiority because of skin color. People from different races also served as soldiers in the Muslim army and administration. Abu Uqba (r), one of the Persian origin freed slave of the Prophet was fighting in the Battle of Ohud, after a powerful sword hitting one of the enemies he said take this hit from a Persian Slave, the Prophet said, "just say from a Persian." ${ }^{\text {65 }}$ Racism in its all forms i.e. individual, institutionalized and cultural is prohibited because it leads to social exclusion. Islam aims to continue peace and unity efforts and to provide security to all peoples and religions.

\section{Conclusion}

Newly converted to Islam from various settings were happy to be connected to this emerging community and their minds were open to accepting new shifts in their thinking, motivations, and values. To achieve the goal of social inclusion, the early Muslim society was built around solidarity, peace of mind, and the idea of unity in diversity. The rights of ethnic, racial, and religious minorities were fully protected. A significant number of followers of Islam were from Africa, many of them were brought as slaves to Arabia which rose the issue of Mixed-Race (AfricanArab children) and anti-black racism was handled successfully. Also, many of the freed Muslim African slaves became members of the ruling elite with strong and equal family ties. There was diversity within the family of Prophet (PBUH), and he made utmost efforts to unite the communities through honest openness, racial and social integration. $\mathrm{He}$ never encouraged racial prejudices and acts of violence. His positive attitude about racial differences created an environment of mutual respect. Islamic norms and values removed the barriers to cross-race friendships 
and social networks. Black children and Arab children did not remain strangers to de facto segregation in the neighborhood. Indigenous Muslims of Arabia never felt threatened by the blacks and non-Arabs. The rising number of diversified converts to Islam transformed a tribal Arabian sect from paganism (Jahiliyya) to an organized and active follower of a universal religion. People without tribe, coming from hunger, victims of slavery, and all other individuals were treated equally and fully integrated into society. There was no gender-based discrimination and violence. The Prophet had a deep commitment to foster a positive and meaningful dialogue as well as to promote peace and interfaith unity in Arabian Peninsula. Early Muslim communities signed treaties with people of other faiths for political and social alignments (as with Jews and Christians). Socially responsible early Muslim community engaged the citizens wisely and made it possible to get in contact with different communities of faith and to integrate people of all regions, religions, ages, and origins. Masjide-Nabvi provided a platform for interfaith forums leading to the world, especially Arabian Peninsula a better place for everyone.

\section{References:}

1 Anshuman Mondal, "Islam and Multiculturalism: Some thoughts on a difficult relationship", Brunel University, Accessed January 10, 2020.

${ }^{2}$ Mazari, Shireen M. "Multiculturalism and Islam in Europe." Policy Perspectives 7, no. 1 (2010): 91-101. Accessed January 13, 2020. www.jstor.org/stable/42909256.

3 Thomas Sealy, "Identity, Difference, Religion: Multiculturalism and British Converts to Islam" (Ph.D. diss., University of the Bristol, Bristol, 2018).

${ }^{4}$ Tina Besley and Michael A. Peters, "Islam and the End of European Multiculturalism?" in Teaching, Responsibility, and the Corruption of Youth Vol 71. (The Netherlands: Koninklijke Brill NV, Leiden, 2019).

${ }^{5}$ Edith B. Ordway. A Book of Synonyms and Antonyms, London, George G. Harrap \& Co Ltd. 1932, p. 70

${ }^{6}$ Chambers Essential English Dictionary. Edinburgh, Chambers Harrap Publisher. 1998, p. 219

${ }^{7}$ Wilhelm Schmidt. The Cultural Historical Method of Ethnology in Encyclopedia Britannica, tr. by Sieber. Chicago, William Benton Publisher, 1980 15th edi., p.367

${ }^{8}$ Reader's Digest Reverse Dictionary.New York, The Reader's digest Association Limited, 1989, p.128

9 Tariq Modood, Multiculturalism, (UK: Polity Press, 2007), 47.

${ }^{10}$ Al- Hakim al-Nishapuri, Abu Abdu-Allah Muhammad ibn Abd-Allah al-Hakim, AlMustadrak ala as-Saheehayn (NG).Karachi: Qadimi Kutub Khana Vol.5 p.62 and also see Qadeer Khan's article on Bhopal, Kerala and Shaqqul Qamr in Daily Jang Karachi March 3, 2010 p.7

${ }^{11}$ Bhatti, Muhammad Ishaq. Bar saghir mi Islam ke Awwalin Nuqush Lahore: Idara Saqafat Islamiyyah 1994, Pp.41-44, Hhatti has mentioned a name list of 25 companions of the Holy Prophet (PBUH) who arrived in medieval Sub-continent.

${ }^{12}$ Muhammad Hamidullah. Islami Riyasat Lahore: Faisal Nashran 2005, Pp. 111-112 
${ }^{13}$ Abul Hasan, Ahmed b. Yahya b. Jabir al blazari. Futuhul Bulda. Beirut: Dar al kutub al Almiyah 2000, p. 50

${ }^{14}$ Futuhul Buldan p.47

${ }^{15}$ Ibid p.199

${ }^{16}$ Ibid p.54-55

${ }^{17}$ Ibid p.41

${ }^{18}$ Ibid p. 28

${ }^{19}$ Al Salihi, Muhammad bin Yousuf . Subulul Huda wal rishad fi seerat khairul anam Beirut : Darul Kutub al Ilmiyyah (1414 h), Vol.2 p.129

${ }^{20}$ Al- Qustalani, Ahmad bin Muhammad. Al-Mwahib al Ladunniyah. Gujrat (India) Markaz Ahlussunnat Barakat Raza .(2001), Vol. 1, Pp. 268-269

${ }^{21}$ Futuhul buldan p.281

${ }^{22}$ Abu Abdullah Ahmad bin Muhammad bin Hanbal Ash Shaibani Musnad Imam Ahmad b. Hanbal, Musnad Abdullah b. Abbas Riyadh: Darussalam Hadith no. 2495. 2012, Vol. 2. p.481

${ }^{23}$ Ibn Hajr Asqalani, Ahmed b. Ali. Fathul Bari Lahore: Darun Nashrul Kutubul Islamiyyah Vol.7 p. 393

${ }^{24}$ Ibid Vol.7 p. 393

${ }^{25}$ Martin Lings. Muhammad (PBUH).Lahore: Suhail Academy 1994, p.216

${ }^{26}$ Musnad Imam Ahmad b. Hanbal, Musnad Abdullah b. Abbas vol. 2 hadith 2456

${ }^{27}$ Muhammad b. Abu Bakr, Ibn al Qayyim Hanbaly. Zadul Maad Egypt: Matbua mustafa al-Babi Vol.1, Pp-34-36

${ }^{28}$ Tirmidi, Abwabul libas bab no. 30. ma jaaa fi lubsil jubbat Hadith no 1768

${ }^{29}$ Muhammad bib Yousuf Salihi Shami, Subulul huda wal reshad fi seerat khairul ibad Chapter \#3 Qalansuwa vol.7 p284 see Maktaba Shamilah

${ }^{30}$ Tirmidi Abwabul Adab Bab no. 55 ma jaa fil khff al aswad Hadith no 2820

${ }^{31}$ Al- Bukhari, Muhammad Ibn Ismaiel. Sahih Bukhari, Kitab no. 51, Kitabul Hibah bab no 28 qubulul hadya nimal mushrikin hadith no. 2615

${ }^{32}$ Ibn Hasham. al Sirat al Nabawiyya. Beirut: Darul Khair 2004, p.192 V.3

${ }^{33}$ Ibid p.221 V.4

${ }^{34}$ Futuhul Bulda. p. 134

${ }^{35}$ Ibid p.41

${ }^{36}$ Ibn Athir, Izzuddin abul Hasan Ali b. Muhammad.(2012). Usudul Ghaba fi Marifat al Sahaba Beirut: Dar ibn Hazm p.13 (18)

${ }^{37}$ Nadvi, Mujibullah. Ahl Ktab Sahaba wa Tabiin. Pakistan, National Book Foundation 1986, p.8

${ }^{38}$ Sahih Bukhari Kitabul Jihad no. 56, bab no.177. Hadith no 3071 \& Kitabul libas no. 77 bab. No 32 Hadith no. 5845 \& Hadith 5832 bab 22 and Kitabul Adab. Bab 17 Hadith no 5993 and Abu Dawud, Sulaiman bin Ashas, Sunan-e- Abi Dawud Hadith no.4024 . Riyad: Maktaba al Maarif p.720.

${ }^{39}$ Muhammad bin Ismail Bhkhari, Sahih Bukhari Kitabul Jihad 52, Hadith 306.

${ }^{40}$ Ibid, Kitabul Fitan no. 92 bab no. 5 Zuhurul-Fitna Hadith nos. 7062-7067.

${ }^{41}$ Imam Muslim, Sahih Muslim. Kitabul Ashribah bab no. 19 Hadth no 5312.

42 Ibid, Kitab salatul Eidayn bab no.4, al rukhsat fi allab allazi la masiyat fihi Hadith nos. 2061-2064.

${ }^{43}$ Ibid, Kitab al-Janaiz Bab n. 24, al qiyam lil Janaza Hadith no. 2217.

${ }^{44}$ Sahih Bukhari. Kitabul Mad bab no. 11, Ayadtul Mushrik Hadith no. 5657.

${ }^{45}$ Sahih Muslim. Kitabul Musaqat wal Muzaraa bab. 24 al-Rahn wa Jawazihi fil Hasr Hadith nos. $4114-4116$. 
46 Talib Hashmi. wfud e Arab barghah Nabvi mai Lahore: Taha Publications 2007, p.14.

${ }^{47}$ Sahih Muslim. Kitabun Nikah bab no. 24, Jawazul Ghilah, Hadith nos.3565 and 3568.

${ }^{48}$ Ibid, Kitabul-libas wa zinah bab 13 fi itikhazun Nabi Khatimn Hadith nos. 5480-5482.

${ }^{49}$ Al-Hakim Nishapuri, Abu Abdullah, Muhammad b. Abdullah(2002). al-Mustadrak ala Sahihain Beirut: Darul Kutub al Ilmiyah Vol.3 p. 633.

${ }^{50}$ Sahih Bukhari, Kitabul -Ahkam no.93 bab no,4 babul sama wa al-Taaa lilimam ma lm tkn Masiyah Hadith no. 7142.

${ }^{51}$ Cyril Glasse .The Concise Encyclopedia of Islam London: Stacey International 2002, p.88.

${ }^{52}$ Sahih Bukhari, Kitab al manaqib bab Manaqib Bilal Hadith 3754.

${ }^{53}$ Abdul Hameed Mahmod Tahmaz. Al-Sayyida Khadija Damasqas: Darul Qalam 1996, p.60.

${ }^{54}$ Sahih Muslim. Ktabul Janaiz bab no. 23, Al Salat alaal Qabr Hadith n, 2215.

55 John L Esposito. The Oxford Dictionary of Islam New York: Oxford University Press 2003, p.5.

${ }^{56}$ Futuhul Buldan p. 134.

${ }^{57}$ Ibid.

${ }^{58}$ Al Baihaqi, Abu bkr, Ahmed b. al- Hussain , Baihaqi Hadith \# 4772 Riyadh: Maktabaul Rushd 2003, p.131, Vol.7.

${ }^{59}$ Sahih Bukhari, Kitabul Iman \#2 (the book of Belief/faith) Hadith \#30 Chapter Sins are from ignorance and a sinner is not a disbeliever unless he worships others along with Allah.

${ }^{60}$ Tirmidi, Abwab al-Manaqib bab no. 70, fadlul Ajam Hadith no. 3932.

${ }^{61}$ Abu Abdullah Ahmad bin Muhammad bin Hanbal al Shaibani.Musnad Imam Ahmad bin Hanbal Cairo: Mowassisa Qurtaba Chapter Hadith abu Burza al aslami Hadith \# 19799 (NG) Vol. 4 p. 422

${ }^{62}$ al Haziz al-Haithami, Noorud din Ali bin Abi Bkr . Majma al Zawaed wa manbae al fawaed Beirut: Darul Fikr 1992, Vol. 1 p.241.

${ }^{63}$ Abu Bakr al Qurtabi, Abu Abdullah Muhammad bib Ahmad . al-Jami lahkam al Qur'an Beirut: Mowassisa al Resalah 2006, Vol.4 p. 282.

${ }^{64}$ Ibid Vol.4 p. 281.

${ }^{65}$ Mishkatul Masabih, bab almfakharat wl asabiyya. 